\title{
A New Electrode-type Mold Level Meter in Continuous Casting Machines
}

\author{
Hiroshi ImAda, Yoshitaka Nimura, Hideki Yokoyama \\ Yasuo SuzukI, Shinzo IIDA, and Yukio OzAKI
}

\begin{abstract}
Synopsis :
This paper is concerned with a new electrode-type mold level meter to be used in the mold of continuous casting machines, and with a mold level control system. The principle of this meter is as follows : the electric resistance of flux on molten steel in the mold is detected by the electrode of the level meter. The displacement of the electrode is controlled in such a way that the resistance, which is equivalent to the distance between the electrode and the molten steel surface, has a constant value. Hence the electrode smoothly follows the movement of the free surface of the molten steel. Therefore the mold level can be detected by measuring the electrode displacement. This level control system was analyzed through the use of a simulation model.

The performance of the electrode-type level meter is as follows:(1) maximum range of use :500 $\mathrm{mm}$, (2) maximum follow-up control speed : $70 \mathrm{~mm} / \mathrm{s}$ and (3) response time : $1 \mathrm{sec}$.

Even in the case of applying the electro-magnetic stirring in the mold, it has been confirmed that the electrode-type level meter can perform so well as to keep the change of molten steel level within $\pm 5 \mathrm{~mm}$ under the automatic operation.
\end{abstract}

\section{1. 緒言}

連続鋳造設備（以下，連鋳機と呼ぶ）が 1955 年に日 本で最初に稼働して以来, 連鋳機の有用性が認められ, いまや,転炬一連続鋳造法が製鋼法の主流となつている。 連続鋳造技術が普遍化してくるにつれて，治金学的な研 究開発はもちろんのこと，最近では，省エネルギー，省 力, 歩留り向上の限界への挑戦を図るために計測制御技 術の研究開発が活発に進められている.とくに最近では 高級鋼の連鋳化が指向されて拈り，一部の鋼種を除いて ほとんどのるのが連鋳化されている. 連鋳鋼種の拡大は 溶銑処理技術, 自動鋳込久技術, 2 次冷却水制御技術や 電磁穓拌技術などの一連の連続鋳造技術の結集により始 めて可能になるものであり, 計測制御技術の果たす役割 は非常に大きい。

自動鋳込み技術の開発にあたつて最大の難点は溶鋼レ ベル計であつた. 従来, 溶鋼レベル計として実用化され
たものには，(1) $\gamma$ 線式レベル計，(2) 熱電対式レベル 計1)2)，(3) 渦電流式レベル計3)，(4) 電磁測温式レベル 計4)などが報告されている.これらのレベル計にはいず れも一長一短があり，とくに最近の高級鋼の連鋳化を指 向した鋳型内電磁靦拌技術と共用できるレベル計は少な い.

筆者らは，以上の状沉に対処するために鋳型内電磁挸 拌技術と共用できる溶鋼レベル計として電極追従方式に 基づく鋳型内溶鋼レベル計を開発した、本報告では，

（1）電極式溶鋼レベル計の原理と構成，(2) 自動鋳込み システムの概要，(3) 制御システムの制御性の検討, (4) 電磁齅拌の影響，(5) 操業結果について述べる.

\section{2. 電極式溶鋼レベル計の原理}

電極式レベル計は, 従来より, いろいろな分野で利用 されているが，いずれの場合も電極と溶鋼との接触/非 接触により電気的導通/非導通状態を ON-OFF 的に検

Trans. ISIJ Vol. 22 (1982) No. 12 に掲載 昭和 56 年 12 月 7 日受付 (Received Dec. 7, 1981)

* (株) 神戸製鋼所浅田研究所 (Asada Research Laboratory, Kobe Steel, Ltd., 53-3 Aza-maruyama Gomo Nada-ku Kobe 657)

*2 (株) 神戸製鋼所加古川製鉄所 (Kakogawa Works, Kobe Steel, Ltd.)

*3 (株) 神戸製鋼所神戸製鉄所 (Kobe Works, Kobe Steel, Ltd.)

*4 (株) 神戸製鋼所機械事業部 (Machinery Division, Kobe Steel, Ltd.) 


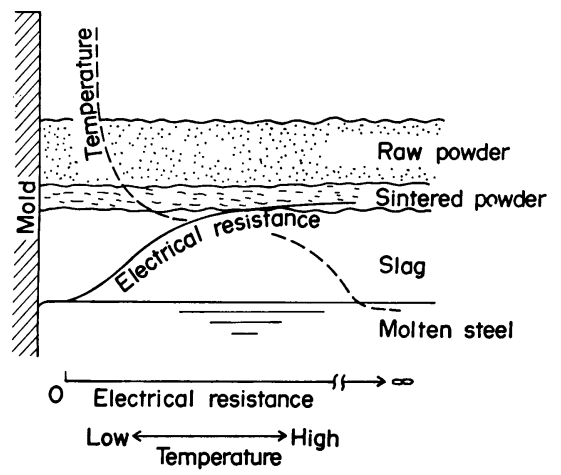

Fig. 1. Diagram illustrating the structure and the electrical characteristic of molten flux in a mold.

知しレベルを測定する方法である5).

本方式は，連鋳機の鋳型内溶鋼レベルの検出を目的と しており，測定原理として鋳型内に添加されているパウ ダーの電気特性を利用している. したがつて, 従来の ON-OFF 式レベル計と異なり，連続的に溶鋼レベル変 化を検出することができる.

\section{$2 \cdot 1$ 鋳型内溶融パウダーの電気的特性}

鋳型内の溶鋼表面には, 保温, 2 次酸化防止, 介在物 の吸収，鋳型-鋳片間の潤滑などを兼ねてパウダーが添 加されている，パウダーは自動供給装置により，鋳型内 へ均一に添加され，通常 5〜 50 mm の厚さで溶鋼表面を 覆つている．溶鋼表面上のパウダーの状態を Fig. 1 に より示す. 添加されたパウダーは高温の溶鋼に接してい るために, 溶鋼表面直上では, 溶融状態のスラグ層, そ の上では温度がやや低くなるので，溶融しないで焼結状 態になつた焼結層, 最上端では, ほとんど添加されたま まの状態の生パウダー層の層構造になつている.

各層の境界は, 明確には区別できず, パウダーの厚み により層状構造も変化し, 極端に薄くなるとスラグ層 だけになることもある.ここで，注目されるのは，スラ グ層内の電気的特性であり, 焼結層および生パウダー層 は関係しない.Fig. 1 に模式的に 3 層構造になつたとき のパウウダーの温度分布および電気抵抗分布を示してい る. とくに，スラグ層内では，パウダーが溶融状態の導 電体になつているので, 電気抵抗の変化は顕著である. すなわち，溶鋼表面近傍では抵抗は低いがスラグ層と焼 結層の境界近傍から急激に抵抗值は大きくなる. スラグ 層内の電気抵抗の実測例を溶鋼表面からの距離の関数と して, Fig. 2 に示す. スラグ層は, 熱伝導率が低いため 層内の温度匂配が大きく, 溶鋼表面から離れるに従つて, 電気抵抗は指数関数的に増加する. Fig. 2 により示した 電気抵抗特性は $\mathrm{SiO}_{2}$ および $\mathrm{CaO}$ を主成分とするパウ ダーの測定例であり，この特性はパウダーの成分が変わ

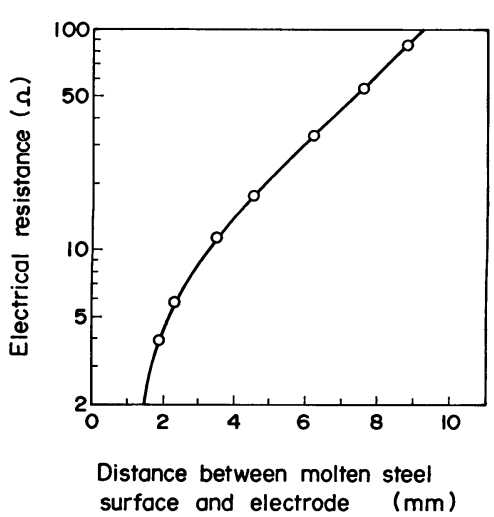

Fig. 2. Electrical resistance of molten flux plotted against distance between molten steel surface and electrode.

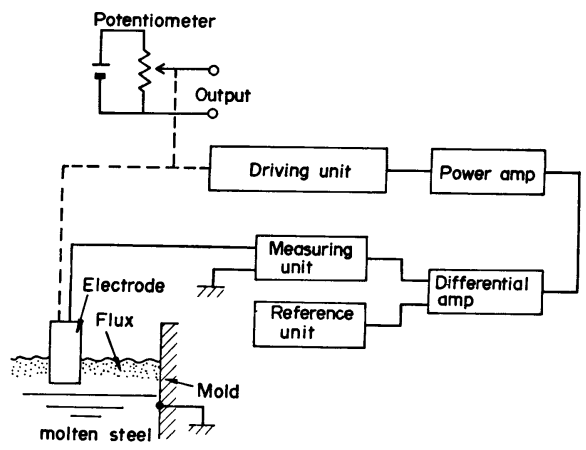

Fig. 3. Block diagram of the electrode-type level meter.

ると当然变化するものである．しかしながら，溶鋼面か らの距離とパウダーの電気抵抗との関係が指数関数的に 変化するという点に扣いて同様なので, 以下に述べる測 定原理から，実用的にはパウダーの相違は無視してもさ しつかえない。

\section{2 測定原理}

鋳型内溶鋼レベル計として従来より電極式レベル計に ついてのいくつかの提案がなされている5). しかしいず れの場合も, 電極と溶鋼との接触を ON-OFF 的に検知 する方法である. これらの方法は, 多くの問題点を有し ており，いずれも実用化されていない，本方式は，見か けは従来方法と同等であるが，原理的には全く異なつて いる. 以下に，本方式の測定原理について述べる.

電極式レベル計の原理図を Fig. 3 に示す. 電極は, 溶鋼表面から少し離れたスラグ層内に浸漬されており, この電極によりスラグー溶鋼-鋳型間の電気抵抗を測定す る. 溶鋼和よび鋳型の電気抵抗は, スラグ層の電気抵抗 に比べて非常に小さく無視できるので，実質的にはスラ 


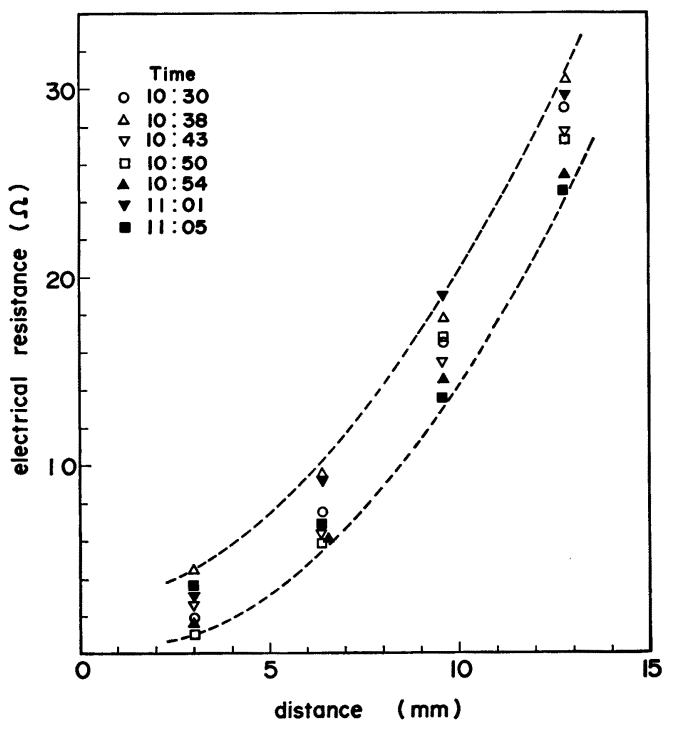

Fig. 4. Electrical resistance fluctuation of powder.

グ層の電気抵抗を測定していることになる.一方，Fig. 2 に示した抵抗特性曲線を利用して電極を設定する位置 をきめ，その位置での電気抵抗を設定抵抗として与え る. 設定抵抗と 実測した 抵抗値との 差は, 増幅器を経 て, 電極駆動用モータに加えられ, サーボ機構により, 電極位置と溶鋼表面との距離が一定になるように制御さ れる.この電極の位置を電極駆動機構に連動させたポテ ソショメータで読み取り，溶鋼レベル位置を検出する. 電気抵抗測定回路の分解能は $0.1 \Omega$ 以上, $75 \mathrm{~mm}$ 振幅の ステップ入力に対する応答特性はムダ時間 0.05 秒, 90 $\%$ 応答は 0.66 秒である. また $10 \mathrm{~mm}$ 振幅の正弦波入 力に対する周波数応答特性として振幅は $0.8 \mathrm{~Hz}$ まで応 答し，位相は $0.5 \mathrm{~Hz}$ まで平担である.上記の特性によ り，本レベル計は鋳型内溶鋼レベル計として十分な特性 を有していることがわかる.

この測定原理より明らかなように，電極と溶鋼表面と の距離は常に一定になるように制御されているので, 溶 鋼レベル変動になめらかに追従できる.

上述のごとく，本方式は溶鋼表面上に添加されたパウ ダーの電気抵抗特性を利用しているのでこの特性が常に 安定しているかどらかが問題である. まず最初に問題に なるのはパウダーの種類が変化したときであるが，本レ ベル計は電気抵抗測定機能を有して括り，使用するパウ ダーに対して Fig. 2 と同様な抵抗特性曲線を簡単に測 定できる．その結果からパウダーの種類に応じて設定抵 抗を変更することによりこの問題は解決できる．パウダ 一の時間経過による電気抵抗の変化を測定した例をFig.
4 により示す. この図は約 $30 \mathrm{~min}$ にわたつて電気抵抗 特性がどのように変化するかを示している．各データは 数分間隔で測定した.この図からわかるように設定抵抗 值に対して時間的に 2 3 mm のレベル变動が生じるこ とになるが溶鋼レベル変動を $\pm 5 \mathrm{~mm}$ 以内に制御するこ とを目的にしているので，この程度の特性曲線の変化は 問題ない.

一方もつと深刻な問題はパウダー層の厚さが極端に薄 くなつたときに生じる.この場合には，レベル計がハン チングを起こす. パウダ厚さが急激に変化したときのレ ベル計の振舞いについては第 4 章で検討する.

\section{3. レベル計の構成}

電極式レベル計は Fig. 3 に示すように電極, 電気抵 抗測定回路, サーボ機構および電極昇降装置により構成 されている. 以下に各部について詳述する。

\section{1 電 極}

本装置の実用化にあたつて最も困難な点は, 電極材料 の選定である. 電極は常に $1500^{\circ} \mathrm{C}$ 以上にも達する溶融 状態のスラグ層に接触しているので，まず，耐熱性が要 求される. 次に電極と溶融スラグ，または，地金との需 れ性が問題になる.このため電極材料としては，ほとん どの金属材料は使用できない。たと艺，チタンのよう に融点の非常に高い材料を使用しても，パウダーが電極 の周囲にダンゴ状に付着して，すぐに測定不能になる. すなわち，電極に付着したスラグは，電極に高抵抗の物 質を皮覆したと同等の作用をする. その結果，正確な電 気抵抗測定ができなくなりレベル計が動作不良を起こ す.

電極材料の選定にあたつて, 種々の材質を対象にした 実験を行つた結果, カーボン系の材質が最適であること が判明した. カーボン系材質は高温の酸化雾囲気では消 耗が激しく，スラグ表面の空気と接触する場所でくびれ が生じる.たとえば非断熱性パウダーを用いた場合はパ ウダー表面は赤熱化し非常に高温になるので数チャージ で 1〜2 mm の損耗が生じる. しかしながら断熱性パウ ダーを使用する場合は, 空気と接触している部分の温度 が低いのでくびれはほとんど起こらない.くびれを防止 するためには，電極表面に耐熱性材料をコーティングす るなどの処理をすることが有効である。

\section{2 電気抵抗測定回路}

電極ースラグ層-溶鋼-鋳型間の電気抵抗を測定する回 路を Fig. 5 で示す. 電極-鋳型間に $500 \mathrm{~Hz}$ の定電流回 路を接続し，抵抗測定を行つている. 直列に接続された 各抵抗要素のらち, スラグ層以外の抵抗要素は, ほとん 


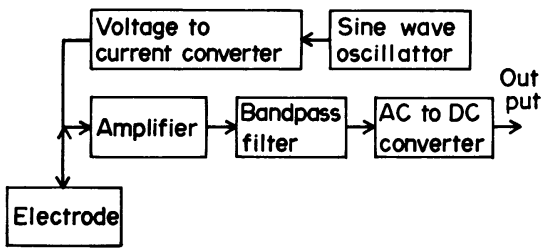

Fig. 5. Block diagram of the resistance measuring unit.

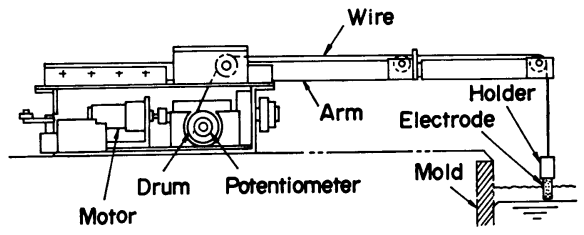

Fig. 6. Side-view of the electrode-type level meter.

ど無視できる大きさである．溶鋼レベル計は，鋳型内電 磁摬拌をかけた状態で使用されるので，低周波誘導ノイ ズおよび商用周波数によるノイズを避けるために，測定 周波数として $500 \mathrm{~Hz}$ が選ばれ，バンドパスフィルタを 通して不要な周波数帯域の信号を除去できるように対ノ イズ対策を施している、レベル計出力は上記フィルタお よび AG-DG 変換回路を通して直流信号に変換され， 設定抵抗值との比較回路に加えられる.

\section{3 サーボ機構}

抵抗測定回路により測定した 電極一鋳型間の 抵抗值と 設定抵抗値との差信号を差動増幅器および電力増幅器に より増幅し, 昇降装置の駆動モータに入力する.このサ 一ボ系による電極の最大追従速度は $70 \mathrm{~mm} / \mathrm{s}$ である. この最大追従速度は，スライドノズル全開のときの溶鋼 流量鋳型断面積，鋳造速度等の関係から決められた。

\section{4 電極昇降装型}

サーボ機構により電極昇降装置の 駆動モータを動か
し，ワイヤを経て電極を昇降させる. レベル計の概観図 を Fig. 6 に示す. 電極位置はワイヤ巻き取りドラムに 直結したポテンショメータにより検出する. 電極の支持 にワイヤを用いることにより, 測定レンジの拡大が容易 にできる．電極の上昇はドラムによりワイヤを巻き取る ことで行う. 一方，下降時にはワイヤがドラムから繰り 出され，電極は自重によつて降下する.

昇降装置には電極の移動範囲を設定するための上下限 リミットスイッチ拉よびワイヤ巻き取り時の異常による ワイヤ切断や下降時に電極が何かに引つ掛かつたとき余 分なワイヤの繰り出しを避けるための張力リミットスイ ッチを備えている.

\section{4. 自動鋳造システム}

連鋳機の自動鋳込みシステムを Fig. 7 で示す. 全体 のシステムは，(1) タンディッシュ内の溶鋼重量制御お。 よび (2) 鋳型内の溶鋼レベル制御の 2 段階に分かれて いる. 前者は，ロードセルにより溶鋼重量を測定し，ス ライドノズルの油圧ュニットにフィードバックして溶鋼 重量変動を $\pm 0.5 \mathrm{t}$ に制御している. 後者の場合, 溶鋼 レベル計の出力をスライドノズルの油圧ュニットにフィ ードバックしてスライドノズルの開度制御を行い, 鋳型 内溶鋼レベル制御を行つている.

本システムにより 鋳型内溶鋼 レベルを制御した例を Fig. 8 で示す. この例でみられるよらに手動運転の場合 にはノズル開度はステップ状に制御されるため, 短周期 の変動は少ないが 長周期のレベル 変動がみられる. 一 方, 自動運転の場合には, 連続的にノズルの開度制御が 行われるのでレベル変動は非常に小さくなつている. 手 動運転の場合のレベル変動は $\pm 20 \mathrm{~mm}$ 程度であるが, 自動運転の場合には, $\pm 5 \mathrm{~mm}$ 以内の変動で安定にレべ ル制御が行われている.

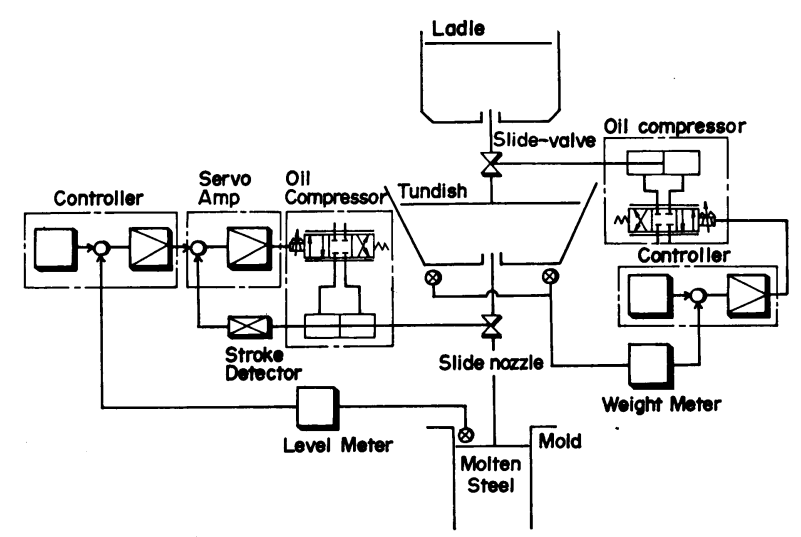

Fig. 7. Automatic casting system in a continuous casting machine. 


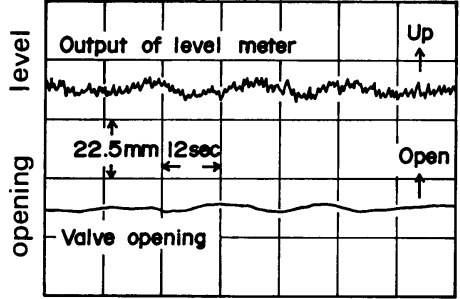

(a)

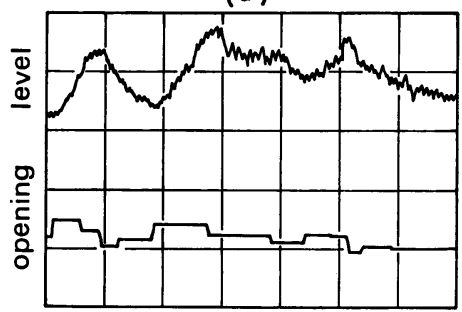

(b)

time

(a) automatic level control

(b) manual level control

Fig. 8. Results of level control in the mold.

\section{5. 考}

察

\section{$5 \cdot 1$ 電極へのスラグの付着}

電極へのスラグの付着は電極材料だけでなく, 電極の 動作に密接に関連している. 電極へのスラグの付着現象 は次のように考觉ることができる。電極は，サーボ機構 によりスラグ層内で微小変位を繰り返している．この変 位量が何らかの原因で大きくなり，スラグ層から引き上 げられた場合，電極に付着したスラグは急激に冷却され， 固化する.この状態で再びスラグ層内に浸漬されると， 固化したスラグ上に，再びスラグが付着する。このよう に電極がスラグ層内からの出入りを頻繁に繰り返すと, 付着したスラグはダンゴ状に成長してゆくしたがつて 従来法による電極式レベル計の場合のように, ON-OFF 的なレベル検出方法では濡れ性の悪い材料を用いても， スラグの付着が必ず起こる，一方，本方法のように，サ 一ボ機構を用いて連続的にレベル検出を行えば，電極の 移動量は非常に小さくなり，スラグ付着の問題は，ほと んど解決できる。

\section{$5 \cdot 2$ スラグの電気抵抗特性}

Fig. 2 に示したスラグの電気抵抗特性は，スラグ厚さ と共に変化する．そのときのレベル計の振舞いと制御性 について以下で検討する．レベル計の応答特性の解析に あたつて, 調節系には PI 制御を用い，レベル計は通常 のサーボ機構としてシミュレーションを行つた。また， 外乱として，制御システムに正規外乱を加えた。

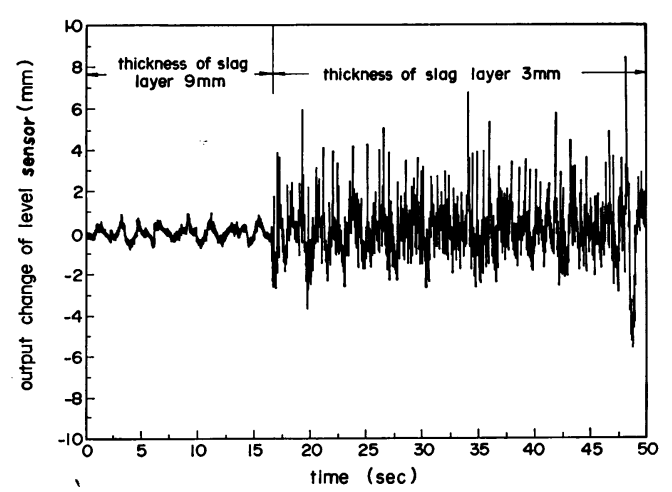

Fig. 9. Illustration of an out-put change of the level meter with thickness change of slag layer from $9 \mathrm{~mm}$ to $3 \mathrm{~mm}$.

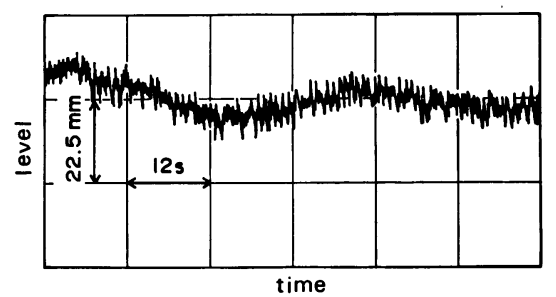

Fig. 10. Diagram illustrating result of electrode hunting when meter is used in thin slag layer.

溶融スラグの厚さが $9 \mathrm{~mm}$ から $3 \mathrm{~mm}$ に変化したと きのレベル計の応答を，Fig. 9 と示す. この図から明ら かなようにスラグ層が極端に薄くなると，レベル計の振 幅および振動周波数が大きくなり，いわゆる，ハンチン グ現象を起こしていることがわかる．これは，スラグ層 が薄くなると，レベル変動に対する抵抗特性が大きく変 化して，わずかなレベル変動に対してもレベル計の電極 位置を制御するゲインが増大する．その結果，外乱に対 して非常に敏感になるためである.この現象は, Fig. 10 にみられるようにレベル計出力の記録に，実際に観測さ れている. 一方, 溶鋼レベルの変動は Fig. 9 のレベル 計出力とは少し様子が異なる. その様相を Fig. 11 のシ ミュレーション結果により示す.これは溶鋼流量制御系 の応答特性がレベル計の特性より悪く, 高い周波数の入 力に対して応答できないためである．また，スラグ層が 薄くなると，レベル変動にオフセットが生じている.こ の現象は次のように説明される. スラグ層の厚さの減少 は，溶鋼レベルの低下とみなされ，スライドノズルに開 度指令が出される，その結果，溶鋼レベルが上昇する. 実際にはスラグ層の厚さはステッブ状には変化しないの で，このような現象はみられないが，長周期のレベル変 動は，このことに起因すると考えられる．以上のことか 


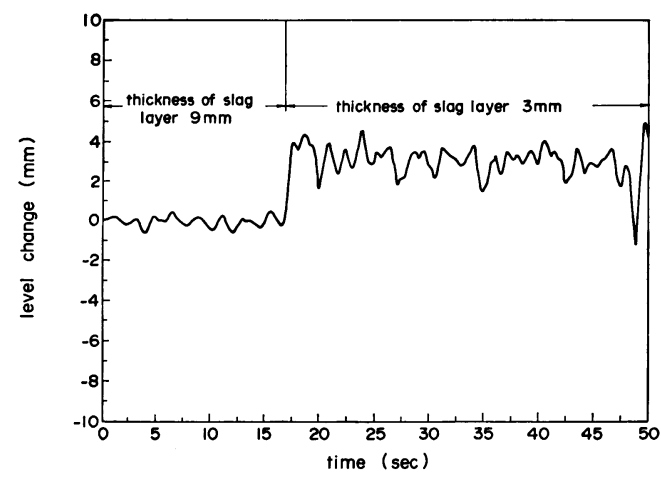

Fig. 11. Diagram illustrating level change when thickness of slag layer changes from $9 \mathrm{~mm}$ to $3 \mathrm{~mm}$.

ら，パウダー厚みは少くとも $5 \mathrm{~mm}$ 以上の厚さになるよ らに管理することが望ましいことがわかる。

\section{3 スライドノズルの流量特性の変化}

鋳型内溶鋼レベル制御システムに加わる外乱には，ス ライドノズルの流量特性変化や鋳造速度の変化などがあ る.スライドノズルの流量特性変化の原因としては,

(1) レードル交換時に顕著にあらわれるタンディッシ 二内の溶鋼重量変動による溶鋼静圧の変化, および (2) スライドノズルの開口面積の変化の 2 つが考えられる. 溶鋼静圧の変化は, このレベル制御システムで, ほとん ど対応できるため大きな問題ではない，一方，スライド ノズルの開口面積の変化の原因には, 鋳造鋼種により溶 損による断面の拡大と $\mathrm{Al}_{2} \mathrm{O}_{3}$ などの析出による閉塞の 2 つがある. 前者の場合は, 制御系のダインが増大した のと同等であり，制御性に重大な影響は及ぼさないが， 後者の場合は, 析出が始まると急速に成長し, 開口面積 が半分以下になることもありらる. 開口面積の減少は制 御系のゲインの減少と同等であり, 極端な場合には, ス ライドノズルを $100 \%$ 開ロしても所定の鋳造速度で鋳造 できなくなる.このよらな状態ではレベル制御はもはや 不可能で $\mathrm{Ar}$ バブリング等により析出した $\mathrm{Al}_{2} \mathrm{O}_{3}$ を取 り除く必要がある.

\section{4 熱奄対式レベル計との比較}

電極式レベル計の特性を他のレベル計と比較するため に従来よりよく用いられている熱電対式レベル計と比較 した. 熱電対式レベル計では, 鋳型表面より $10 \mathrm{~mm}$ の 深さに，垂直方向に $10 \mathrm{~mm}$ 間隔で銅壁に埋め込んだ熱 電対群を用いた. この熱電対群により, 鋳型の温度分布 を測定し，溶鋼レベル位置はその温度分布が最大匂配を 示す位置から検出した. 両者のレベル検出結果を比較し た図を Fig. 12 に示す. 両者ともレベル変動を良く検出

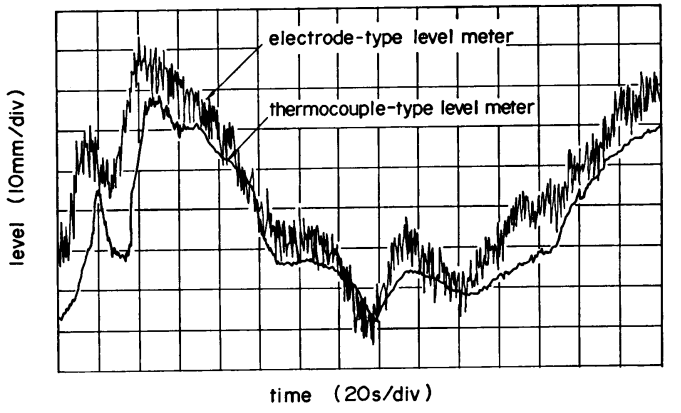

Fig. 12. Out-put of the electrode-type level meter and the thermocouple-type level meter.
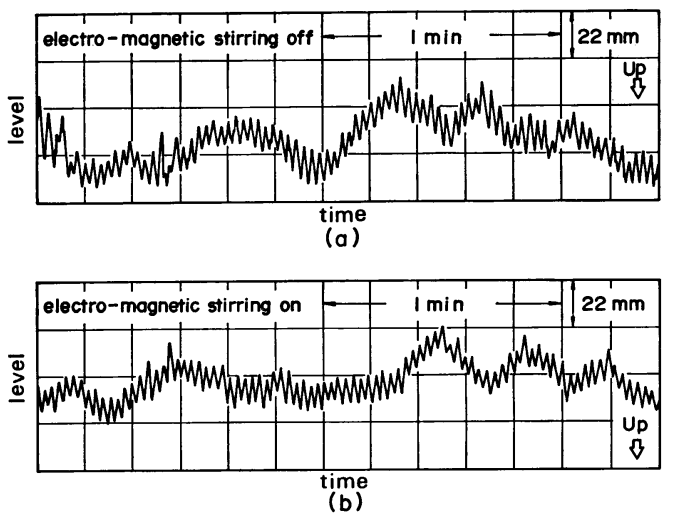

Fig. 13. Effect on out-put of the electrode-type level meter with electro-magnetic stirring in the mold.

しているが，熱電対式レベル計は電極式レベル計より 5 〜 $10 \mathrm{~s}$ 程度の遅れを示している. また，レベル変動の様 子がなまつた形をして和り, 明らかに応答が遅いことが わかる. 熱電対式レベル計を用いて， PI 制御によりレ ベル制御を行らと, 上記の理由により, 制御系のゲイン を高めることが困難で, 突発的な外乱に対して十分に対 応できない.

\section{5 電磁攪找の影響}

最近の高級鋼用連鋳機では, 鋳型内電磁䚁拌が行われ るようになつてきた. 当社のブレーム連鋳機の 場合に は, 鋳型内電磁挸挥装置が設置されている. 電磁挸拌は 鋳型外部から溶鋼に強力な低周波回転磁場をかけること により溶鋼を䚁拌している. そのため, 従来のレベル計 では, 電磁ノイズによる外乱やレベル計の設置方法など 種々の問題が生じる. 特に電磁ノイズの影響は大きく, 熱電対式レベル計では周期的ノイズではあるが, 温度信 号より誘導ノイズ信号の方が大きく検出されるため，レ ベル計として使用するにはかなり問題がある.

電極式レベル計の場合は, 鋳型内電磁挸拌を対象にし 
て開発した経緯もあり, 誘導ノイズは, ほとんど問題に ならない．Fig. 5 に示したように，信号処理装置にも 誘導ノイズを除くために，バンドパスフィルターを入れ ノイズ対策を施している. Fig. 13 にレベル計出力に及 ぼす電磁筧拌の影響を示す. 図の上段 ( a ) は電磁䚓拌を かけていないときのレベル計出力であり, 下段（b)は電 磁穓拌中の因を示している.この図は手動運転時の例で ある.また，この実験では，レベル計を鋳型カバー上に 設置したため，鋳型振動の影響を受けてレベル計出力 が，上下に振動している様子があらわれている．実際の 装置では, タンディッシュカーにレベル計を塔載してい るので鋳型振動の影響はあらわれない。この図から明ら かなように，無靦拌時と電磁摫拌時のレベル計出力を比 較すると, 両者の出力に差異は認められない，

以上述べたように, 電極式レベル計では, 電磁擤拌に よる誘導ノイズの影響は無視できるが，レベル計の構造 に起因する問題がある. 電極昇降装置にはワイヤが用 いられて和り，電極は自重により降下する．そのため, 電極が溶鋼流に引きずられて傾倒し, 誤動作をする. 前 述のごとく, ワイヤを使用する理由は, 測定スパンを容 易に拡大寸ることが可能であり，しか子操作性が良いと いら利点を重視したためである. ワイヤの代わりに，ア 一ムを使用すれば，この問題は解決できるが，上記の利 点は失われる，そこで，溶鋼流の最大流速を考虑して電 極ホルダの重量を増加させること，および，ワイヤに振 れ止め機構をつけることなどの対策を施し，電極が溶鋼 に流されるといら問題点を解決している.

\section{6. 結言}

連鋳機の鋳型内溶鋼レベル制御を行らために電極式レ ベル計を開発し，自動鋳込みシステムを確立した。

\section{1 電極式レベル計の仕様}

（1）測定原理 スラグの電気抵抗特性を利用した電
極追従方式

(2) 測定範囲 $\max 500 \mathrm{~mm}$

（3） 測定精度 $\pm 1 \mathrm{~mm}$

(4) 追従速度 $\max 70 \mathrm{~mm} / \mathrm{s}$

\section{2 電極式レベル計の特徴}

（1）レベル計は小型なのでタンディッシュカーに塔 載でき, 鋳型周辺での作業の障害にならない。

（2）測定範囲が広く, かつ, 測定精度も高い。

（3）ドリフトや誘導ノイズなどの影響が少なく, 電 磁擋拌時のレベル計として最適である.

（4）追従速度が大きく，連鋳機のほとんどの異常時 に対処できる.

（5）メインテナンスが簡単である.

\section{3 自動鋳込みシステム}

自動鋳込みシステムは（1）レードル内の溶鋼重量制 御システムと（2）鋳型内溶鋼レベル制御システムから 構成されている. 各システムの制御精度は, 前者の場合 は, $\pm 0.5 \mathrm{t}$, 後者の場合は $\pm 5 \mathrm{~mm}$ である.

電極式レベル計は, 当社のブルーム連釷機で約 2 年間 にわたるフィールドテストを経て, 種々の問題点の解決 を図り，神戸製鉄所，および加古川製鉄所で設備化し， 現在, 両製鉄所で順調に稼働している.

\section{交献}

1) J. H. WiLson: Instr. Tech. (1971) 6, p. 37

2) 今田 紘, 川田 豊, 小島康德: 神戸製鋼技報, 29 (1979) 3, p. 83

3 ) 佐野和夫, 安藤静吾, 山田健夫, 石黑守幸, 中島 広久, 山田俊郎：日本鋼管技報, 84 (1980), p. 35

4 ) 吉原晃代, 井出上和夫, 関口保明, 鈴木史郎, 西 村 統，佐々木邦政：鉄と鋼，67（1981）8， p. 1128

5) 特許公報：特開昭 49-52125，50-56971, $50-81920$ ，特告昭 46-27224 